\title{
Association of -3826 G Variant in uncoupling protein-1 with increased BMI in overweight Australian women
}

\author{
L.K. Heilbronn ${ }^{1}$, K.L.Kind ${ }^{2}$, E.Pancewicz ${ }^{1}$, A.M.Morris ${ }^{1}$, M. Noakes $^{2}$, P.M. Clifton $^{2}$ \\ ${ }^{1}$ Department of Physiology, University of Adelaide, South Australia \\ ${ }^{2}$ Commonwealth Scientific Industrial Research Organization (CSIRO) Health Sciences and Nutrition, Adelaide, South Australia
}

\begin{abstract}
Aims/hypothesis. To determine whether genetic variation in uncoupling protein-1 (UCP-1) is associated with obesity or obesity-related risk factors in overweight women.

Methods. We genotyped 526 overweight/obese women (mean body mass index $34.1 \mathrm{~kg} / \mathrm{m}^{2}$, range 25.0 to $\left.47.5 \mathrm{~kg} / \mathrm{m}^{2}\right)$ for the $-3826 A \rightarrow G$ uncoupling protein1 polymorphism. Of the 526 women genotyped 144 had fasting blood samples analysed for glucose and lipid measurements.

Results. The $-3826 \mathrm{G}$ allele was found with a frequency of 0.23 and was associated with higher BMI $(p=0.02)$. A higher frequency of this polymorphism (0.33) was found in subjects with Type II (non-insulin-dependent) diabetes mellitus $(p=0.02)$, though
\end{abstract}

adjustment for BMI weakened this significance $(p=0.06)$. The $-3826 G$ variant was associated with increased fasting glucose $(p=0.01)$. This was, however, a result of a greater proportion of women with Type II diabetes also having the $G$ variant ( $p=0.10$, adjusted for Type II diabetes). The $-3826 G$ variant of uncoupling protein-1 did not have an effect on other metabolic variables associated with obesity.

Conclusion/interpretation. In overweight Australian women the $-3826 G$ variant of UCP-1 increased the susceptibility to obesity indicating that UCP-1 could be involved in weight regulation. [Diabetologia (2000) 43: 242-244]

Keywords Uncoupling protein-1, polymorphism, obesity, Type II diabetes.
Uncoupling protein-1 (UCP-1) has been suggested as an obesity gene in humans. It is expressed exclusively in the inner mitochondrial membrane of brown adipose tissue and acts by uncoupling substrate oxidation from ATP generation reducing metabolic efficiency [1]. Brown adipose tissue plays an important part in the regulation of energy expenditure in rodents as animals with BAT dysfunction develop obesity [2]. Its function in humans is, however, less clear.

A naturally occurring variant in UCP-1 that results in an $A \rightarrow G$ base pair substitution in the promoter re-

Received: 23 September 1999 and in revised form: 8 November 1999

Corresponding author: L. Heilbronn, P.O. Box 10041, Adelaide BC, S. A. 5000, Australia

Abbreviations: UCP-1, Uncoupling protein-1 gion $(-3826)$ is observed with a frequency of 0.27 in Caucasians [3]. The $-3826 G$ variant of UCP-1 has been weakly associated with increased weight gain over time in morbidly obese women [4] and resistance to weight loss during moderate energy restriction [5] although it has not been independently associated with a reduced basal metabolic rate [6]. Furthermore, the $-3826 G$ variant has not been associated with BMI in the general population and the distribution of this variant is even between lean and obese subjects $[4,7]$. This suggests that the $-3826 \mathrm{G}$ polymorphism of UCP-1 does not have a large role in obesity. Because the $-3826 G$ variant has, however, been linked to weight gain in obese women, we hypothesise that it will be related to higher BMI in an already overweight cohort. 
Table 1. Physical characteristics of 526 overweight women with $A A, A G$ or $G G$ genotypes of UCP-1

\begin{tabular}{lccccc}
\hline & $A A$ & $A G$ & $G G$ & $\begin{array}{l}\text { ANOVA } \\
p \text { value }\end{array}$ & $\begin{array}{l}\text { Linear trend } \\
p \text { value }\end{array}$ \\
\hline$n$ & & & - & - \\
Age (years) & 307 & 190 & 29 & 0.83 & 0.69 \\
BMI (kg/m $\left.{ }^{2}\right)$ & $47.8 \pm 0.6$ & $48.2 \pm 0.7$ & $35.5 \pm 2.4$ & 0.066 & 0.02 \\
Weight $(\mathrm{kg})$ & $33.88 \pm 0.24$ & $34.65 \pm 0.34$ & $94.3 \pm 2.2$ & 0.24 & 0.22 \\
\hline
\end{tabular}

Means \pm SEM. Statistics are one way ANOVA and linear association

Table 2. Physical and clinical characteristics of 144 overweight women with $A A, A G$ or $G G$ genotypes of UCP-1

\begin{tabular}{|c|c|c|c|c|c|c|}
\hline & $A A$ & $A G$ & $G G$ & $\begin{array}{l}\text { ANOVA } \\
p \text { value }\end{array}$ & $\begin{array}{l}\text { Adjusted } \\
p \text { value }\end{array}$ & $\begin{array}{l}\text { Linear trend } \\
p \text { value }\end{array}$ \\
\hline$n$ & 81 & 55 & 8 & - & - & - \\
\hline Type II diabetes (\%) & $27 \%$ & $35 \%$ & $50 \%$ & $0.02^{\mathrm{a}}$ & $0.06^{\mathrm{a}}$ & - \\
\hline BMI $\left(\mathrm{kg} / \mathrm{m}^{2}\right)$ & $32.5 \pm 0.5[4.5]$ & $33.2 \pm 0.6[4.3]$ & $35.1 \pm 0.6[1.8]$ & 0.21 & - & 0.09 \\
\hline Median BMI & 31.9 & 32.8 & 34.5 & - & - & - \\
\hline Weight (kg) & $86.32 \pm 1.44$ & $87.33 \pm 1.61$ & $99.06 \pm 2.46$ & 0.02 & - & 0.05 \\
\hline Insulin (mU/l) & $12.01 \pm 9.48$ & $13.93 \pm 0.94$ & $18.04 \pm 3.57$ & 0.09 & 0.22 & 0.03 \\
\hline $\mathrm{TG}(\mathrm{mmol} / \mathrm{l})$ & $2.11 \pm 0.09$ & $1.98 \pm 0.11$ & $2.88 \pm 1.06$ & 0.12 & 0.16 & 0.45 \\
\hline HDL (mmol/l) & $1.16 \pm 0.03$ & $1.18 \pm 0.04$ & $1.09 \pm 0.18$ & 0.70 & 0.79 & 0.90 \\
\hline $\mathrm{LDL}(\mathrm{mmol} / \mathrm{l})$ & $3.63 \pm 0.09$ & $3.74 \pm 0.12$ & $3.39 \pm 0.55$ & 0.58 & 0.58 & 0.95 \\
\hline
\end{tabular}

Values given as means \pm SEM [SD]. Statistics are one way ANOVA, with adjustment for BMI when required. ${ }^{\text {a }}$ logistic regression

\section{Subjects and methods}

We recruited 526 overweight $\left(\mathrm{BMI}=25-29.9 \mathrm{~kg} / \mathrm{m}^{2}\right)$ or obese $\left(\mathrm{BMI} \geq 30 \mathrm{~kg} / \mathrm{m}^{2}\right)$ Caucasian women (mean BMI $34.1 \mathrm{~kg} / \mathrm{m}^{2}$, range 25.0 to 47.5 ) by public advertisements that sought overweight women for a weight loss trial. On one occasion overweight women with Type II (non-insulin-dependent) diabetes mellitus were recruited. We extracted DNA from whole blood by Insta Gene DNA extraction kit (Bio-Rad, Sydney, Australia) and genotyped the subjects for the -3826 $G$ variant of UCP-1 by PCR and RFLP methods as described previously [4]. In 144 women fasting blood samples were analysed for plasma glucose, total cholesterol, HDL, LDL (calculated) and triglyceride concentrations using a Cobas-Bio centrifugal analyser (Roche Diagnostica, Basel, Switzerland) and enzymatic kits (Hoffman-La Roche Diagnostica, Basel, Switzerland) and insulin concentrations using a radioimmunoassay kit (Pharmacia AB, Uppsala, Switzerland). Waist circumference was also measured in these women $(n=144)$ as the smallest margin between the rib and iliac crest and a 3-h oral glucose tolerance test (OGTT, $75 \mathrm{~g}$ of glucose) was carried out. Subjects were classified with Type II diabetes if they were receiving oral hypoglycaemic medication (metformin therapy, $n=7$, sulphonyl urea therapy, $n=3$ ) or if at $2 \mathrm{~h}$ after glucose ingestion their glucose concentrations were greater than $11.1 \mathrm{mmol} / \mathrm{l}(n=31)$. Protocols were approved by the Human ethics committee of CSIRO, Health Sciences and Nutrition and subjects gave their informed consent to participate in the study. Statistical analysis was done using SPSS 8.0 for Windows with linear and logistic regression and one way ANOVA before and after adjustment for BMI. Significance was set at $\mathrm{p}<0.05$.

\section{Results}

The allele frequency of the $-3826 G$ variant of UCP-1 was 0.23 . A linear trend was observed between the presence of the $G$ variant of UCP-1 and BMI indicating an effect of genotype ( $p=0.02$, Table 1$)$. Furthermore, when all subjects with the $-3826 G$ variant were compared with subjects without the $G$ variant, BMI was significantly higher (AG/GG, $34.7 \pm 0.3 \mathrm{~kg} /$ $\mathrm{m}^{2}, n=219$, AA, $\left.33.9 \pm 0.2 \mathrm{~kg} / \mathrm{m}^{2} n=307, p=0.023\right)$. Of the 144 women who underwent OGTT, 41 were diagnosed with Type II diabetes. A higher frequency of the $G$ variant (0.33) was found in women with Type II diabetes $(p=0.02$, Table 2$)$. Adjustment for BMI, however, weakened this significance $(p=0.06$, Table 2). Furthermore, the $G$ variant was associated with higher fasting glucose concentrations $(p=0.01$, adjusted for BMI, Table 2). This was due to a greater proportion of subjects with Type II diabetes also having the $G$ variant ( $p=0.1$, after adjustment for Type II diabetes). In the subjects with Type II diabetes, the $-3826 G$ variant was linearly related with higher fasting glucose concentrations ( $p=0.02$, adjusted for BMI, data not shown). A linear association was also 
observed between $G$ variant of UCP-1 and insulin $(p=0.03)$ although not after adjustment for BMI (Table 2). The UCP-1 genotype did not have an influence on waist circumference, LDL, HDL or triglyceride concentrations.

\section{Discussion}

In a large representative sample of overweight Australian women with and without Type II diabetes we found that the $-3826 G$ variant of UCP-1 was positively associated with BMI. The role of UCP-1 in weight regulation is questioned because of the small amount of brown adipose tissue found in adult humans. Nevertheless, UCP-1 mRNA has been detected in intraperitoneal and extraperitoneal adipose tissue, indicating that brown adipocytes are interspersed in tissue previously thought to contain white adipocytes only [8]. Furthermore, the $G$ variant of UCP-1 has been associated with reduced UCP1 mRNA expression [9] indicating that the polymorphism is of functional importance. Recently, a study investigating Japanese men (53 lean, 126 overweight) found that subjects who were heterozygous for the $G$ variant had increased BMI [10]. This was, however, the first study to find an association between BMI and the $G$ variant of UCP-1 in Caucasians. In support of our findings, previous trials have shown that obese women with the $G$ variant were more likely to gain weight over time $[3,4]$ and less likely to lose weight $[5]$.

The role of the $G$ variant of UCP-1 in Type II diabetes has not been examined in detail. One study has found a reduced percentage of the $G$ variant in morbidly obese women with Type II diabetes [4]. In this study, however, a greater frequency of the $G$ variant was found in subjects with Type II diabetes. Furthermore, an association was observed between fasting glucose and $-3826 G$ variant in women with Type II diabetes, independently of increased BMI. The mechanism by which genetic variation of UCP-1 is involved in Type II diabetes is not certain but fatty acid metabolism could be involved.

Association studies in overweight Australian women show that the $G$ variant of UCP-1 is associat- ed with higher BMI suggesting that genetic variation in UCP-1 influences the susceptibility to obesity in overweight people and can also increase the development of Type II diabetes.

Acknowledgements. The authors would like to thank K. Pender, A. McGuffin, P. Foster, R. McArthur, K. Rhodes, M. Whitrow and M. Parrish for assistance in these studies.

\section{References}

1. Nicholls DG, Locke RM (1984) Thermogenic mechanisms in brown fat. Physiol Rev 64: 1-64

2. Lowell BB, Susulic V, Hamman A et al. (1993) Development of obesity in transgenic mice after genetic ablation of brown adipose tissue. Nature 366: 740-742

3. Oppert JM, Vohl MC, Chagnon M et al. (1994) DNA polymorphism in the uncoupling protein (UCP) gene and human body fat. Int J Obes Relat Metab Disord 18: 526-531

4. Clement K, Ruiz J, Cassard-Doulcier AM et al. (1996) Additive effect of $\mathrm{A} \rightarrow G(-3826)$ variant of the uncoupling protein gene and the Trp64Arg mutation of the beta 3-adrenergic receptor gene on weight gain in morbid obesity. Int J Obes Relat Metab Disord 20: 1062-1066

5. Fumeron F, Durack-Bown I, Betoulle D et al. (1996) Polymorphisms of uncoupling protein (UCP) and beta 3 adrenoreceptor genes in obese people submitted to a low calorie diet. Int J Obes Relat Metab Disord 20: 1051-1054

6. Valve R, Heikkinen S, Rissanen A, Laakso M, Uusitupa M (1998) Synergistic effect of polymorphisms in uncoupling protein 1 and beta3-adrenergic receptor genes on basal metabolic rate in obese Finns. Diabetologia 41: 357-361

7. Gagnon J, Lago F, Chagnon YC et al. (1998) DNA polymorphism in the uncoupling protein 1 (UCP1) gene has no effect on obesity related phenotypes in the Swedish Obese Subjects cohorts. Int J Obes Relat Metab Disord 22: 500-505

8. Oberkofler H, Dallinger G, Liu YM, Hell E, Krempler F, Patsch W (1997) Uncoupling protein gene: quantification of expression levels in adipose tissues of obese and nonobese humans. J Lipid Res 38: 2125-2133

9. Esterbauer H, Oberkofler H, Liu YM et al. (1998) Uncoupling protein-1 mRNA expression in obese human subjects: the role of sequence variations at the uncoupling protein-1 gene locus. J Lipid Res 39: 834-844

10. Hayakawa T, Nagai Y, Taniguchi M et al. (1999) Phenotypic characterization of the beta3-adrenergic receptor mutation and the uncoupling protein 1 polymorphism in Japanese men. Metabolism 48: 636-640 